\title{
Progesterone priming and age of ewe affect the life-span of corpora lutea induced in the seasonally anovulatory Merino ewe by the 'ram effect'
}

\author{
C. M. Oldham, D. T. Pearce and S. J. Gray \\ School of Agriculture (Animal Science), University of Western Australia, Nedlands, \\ Western Australia 6009, Australia
}

\begin{abstract}
Summary. Increasing doses of progesterone from 0 to $20 \mathrm{mg}$, given as a single i.m. injection, increased the proportion of corpora lutea that had a normal life-span when induced in ewes by the introduction of testosterone-treated wethers from $54 \%(19 / 35)$ to $100 \%(34 / 34)$. Injection of progesterone did not affect the induction of ovulation and $95 \%(130 / 136)$ of the anovulatory ewes ovulated. Nevertheless, a low proportion of ewes displayed oestrus between Days 16 and 26 after the introduction of testosterone-treated wethers (Exp. 1, 47\%, 92/196; Exp. 2, 50\%, 502/1000). Many of the ewes that did not display oestrus also failed to ovulate again (Exp. 1, 70\%, 37/53). The proportions of anovulatory adult and maiden ewes that ovulated after the introduction of testosterone-treated wethers were not significantly different but significantly fewer maiden ewes were detected in oestrus.
\end{abstract}

\section{Introduction}

The introduction of rams or testosterone-treated wethers to seasonally anovulatory ewes, preconditioned by a period of isolation from rams, stimulates ovulation in many ewes (Schinckel, 1954; Fulkerson, Adams \& Gherardi, 1981). This response has become known as the 'ram effect'. Ovulations induced by the introduction of rams are usually not accompanied by behavioural oestrus (Schinckel, 1954) and are followed by corpora lutea (CL) with a normal or abnormal life-span (Oldham \& Martin, 1978). Ewes with a normal luteal life-span display oestrus for the first time at their second ovulation about 18 days after the introduction of rams. CL with an abnormal life-span usually persist for only 5-7 days and are followed by a second ovulation with normal CL. Ewes therefore display oestrus for the first time at the third ovulation about 24 days after the introduction of rams (Oldham \& Martin, 1978).

After progesterone priming for 12 days (Oldham, Cognie, Poindron \& Gayerie, 1980) or with a single injection of progesterone immediately before the introduction of rams (Cognie et al., 1982) oestrus is confined to a single peak at the first or second ovulation respectively. These data suggest that progesterone may act to eliminate CL with an abnormal life-span. In addition, the effectiveness of the single injection of progesterone appeared to be dose-dependent in that as the dose of progesterone increased to $20 \mathrm{mg}$ the synchronization of oestrus appeared to improve. It was therefore suggested that abnormal CL would be eliminated only at the highest dose of progesterone.

Under field conditions the efficacy of the 'ram effect' is usually measured by the proportion of ewes that display oestrus 16-24 days after the introduction of rams. This varies with breed and strain of ewe, age of ewe and other environmental factors (Oldham, 1980; Murtagh, Gray, Lindsay \& Oldham, 1984): some ewes in the flock may be cyclic and will not respond to the introduction of rams; some anovulatory ewes may not be induced to ovulate while others may not subsequently ovulate again or display oestrus.

The experiments described in this paper were designed to investigate the relationships between the dose of progesterone, administered as a single injection, and age of ewe on the life-span of CL 
and oestrous activity of ewes after the introduction of testosterone-treated wethers. In addition, one experiment investigated whether efficacy of the 'ram effect' could be improved by re-isolating ewes from rams for the period between first ovulation and anticipated oestrus.

\section{Materials and Methods}

A flock of 1196 Merino ewes of mixed age, kept on pasture, were allocated to two experiments in September/October.

Experiment 1 had a $4 \times 2$ factorial design. The treatments were 4 doses of progesterone $(0,5$, 10 or $20 \mathrm{mg}$ in $2 \mathrm{ml}$ oil) and 2 ages (maiden or adult) of Merino ewes. The number of ewes in each subgroup was 34 for adult ewes, and 15 for maiden ewes $(N=196)$.

Experiment 2 had a $4 \times 2 \times 2$ factorial design. The same doses of progesterone $(0,5,10$ and $20 \mathrm{mg}$ ) and ages of ewes (aduit and maiden) were used as in Exp. 1. In addition Exp. 2 tested the effect of continuous or interrupted contact with testosterone-treated wethers. The number of ewes in each subgroup was 84 for adult ewes and 41 for maiden ewes $(\mathrm{N}=1000)$.

Both experiments were run concurrently and all ewes were maintained in isolation from the sight, sound and smell of rams for at least 1 month before the beginning of the experiment. Progesterone was injected intramuscularly immediately before the introduction of testosterone-treated wethers in a proportion of 1 wether/17 ewes (Day 0) (Fulkerson et al., 1981). The wethers remained with the ewes in Exp. 1 until Day 26. In Exp. 2, the wethers were withdrawn from half of the ewes for the period between Days 6 and 14, and then returned to remain with the ewes until Day 26. The wethers were fitted with Sire-sine harnesses and crayons on Day 15 and ewes were checked for oestrus twice each day beginning on the morning of Day 16 and continuing until Day 26.

Groups of ewes in Exp. 1 underwent laparoscopy (Oldham, Knight \& Lindsay, 1976) before the introduction of testosterone-treated wethers on Day $0(\mathrm{~N}=98)$, and again on Day $5(\mathrm{~N}=196)$, Day $12(\mathrm{~N}=196)$ and Day $29(\mathrm{~N}=71)$. The incidences of ovulation and $C L$ with a normal life-span were measured as described previously (Oldham \& Martin, 1978; Oldham \& Lindsay, 1980). Briefly, CL were defined as having a normal life-span if they were present at both the Day-5 and Day-12 laparoscopy.

Injection of progesterone delays the preovulatory surge of $\mathrm{LH}$, and consequently delays subsequent ovulations and the first peak of oestrus relative to the time of introduction of rams (Cognie et al., 1982). For this reason, in Exp. 2 in which normal luteal life-span was determined only from records of oestrus, ewes were deemed to have normal CL if they were detected in oestrus between Days 16 and 20 after injection of 0 or $5 \mathrm{mg}$ progesterone, between Days 17 and 21 after $10 \mathrm{mg}$ progesterone and between Days 18 and 22 after $20 \mathrm{mg}$ progesterone. Spontaneously ovulating ewes could not be separated from ewes induced to ovulate by the introduction of testosterone-treated wethers in these data, but in Exp. 1 the frequency of CL with a normal life-span was measured precisely by laparoscopic examination of the ovaries of ewes induced to ovulate by the introduction of testosterone-treated wethers. The data pertaining to the incidence of ovulation and oestrus and the frequency of CL with normal life-span were treated by analysis of deviance (Nelder \& Wedderburn, 1972). The model was fitted using the statistical computer programme GENSTAT (Alvey et al., 1977). Data for ovulation rate of ewes ovulating were analysed by $\chi^{2}$ tests.

\section{Results}

\section{Experiment 1}

Before the introduction of testosterone-treated wethers $34 \%(32 / 93)$ of the ewes were ovulating spontaneously with a mean ovulation rate of $1 \cdot 30$. After the introduction of the wethers $95 \%$ 
Table 1. Effect of dose of progesterone on the proportion of ewes having normal corpora lutea (CL) measured by laparoscopic examination of the ovaries (Exp. 1) or from records of distribution of oestrus (Exp. 2) (numbers in parentheses are percentages)

\begin{tabular}{lcccc}
\hline & \multicolumn{4}{c}{ Dose of progesterone } \\
\cline { 2 - 5 } & 0 & $5 \mathrm{mg}$ & $10 \mathrm{mg}$ & $20 \mathrm{mg}$ \\
\hline $\begin{array}{l}\text { Experiment 1 } \\
\text { Normal CL }\end{array}$ & $19 / 35(54)$ & $23 / 27(85)$ & $30 / 34(88)$ & $34 / 34(100)$ \\
$\begin{array}{c}\text { Experiment 2 } \\
\text { Incidence of } \\
\quad \text { oestrus }\end{array}$ & & & & \\
Normal CL & $119 / 250(48)$ & $126 / 250(50)$ & $122 / 250(49)$ & $135 / 250(54)$ \\
\hline
\end{tabular}

(130/136) of the anovulatory ewes were induced to ovulate with an ovulation rate of 1.60 which was higher $(P<0.01)$ than that of ewes that were ovulating spontaneously before the introduction of testosterone-treated wethers. There was no effect of dose of progesterone or age of ewe. Laparoscopy on Day 0 before the introduction of testosterone-treated wethers did not affect the induction of ovulation measured on Day 5 when compared with ewes which underwent laparoscopy on Day 5 only (Day 0 and 5, 95\%; Day 5, 95\%).

The single injection of progesterone increased $(P<0.01)$ the frequency of normal $\mathrm{CL}$ from $54 \%$ to $100 \%$ as the dose of progesterone increased from 0 to $20 \mathrm{mg}$ (Table 1$)$. Only $47 \%(92 / 196)$ of ewes were detected in oestrus by the testosterone-treated wethers between Days 16 and 26 . Of the ewes that had not been detected in oestrus by Day 26, but which had originally been induced to ovulate by Day $5,70 \%(37 / 53)$ were found to be anovulatory at laparoscopy on Day 29 .

The adult ewes had a lower frequency of normal $\mathrm{CL}$ than did maiden ewes $(77 \%, 67 / 87$ compared to $90 \%, 39 / 43 ; P<0.05)$ and a higher incidence of oestrus between Days 16 and 26 than did maiden ewes $(51 \%, 70 / 136$ compared to $37 \%, 22 / 60 ; P<0.05)$.

\section{Experiment 2}

The dose of progesterone had no effect on the incidence of oestrus between Days 16 and 26 $(50 \pm 1 \%$, mean \pm s.e.m.) but did affect the proportion of ewes that displayed oestrus after a normal CL ( 0 and $5 \mathrm{mg}$ compared to 10 and $20 \mathrm{mg} ; P<0.001$; Table 1 ).

The continuous or interrupted presence of testosterone-treated wethers had no effect on the incidence or distribution of oestrus, but the incidence of oestrus varied with age of ewe: $60 \%$ $(401 / 672)$ of adult ewes but only $33 \%(109 / 328)$ of maiden ewes displayed oestrus $(P<0.001)$.

\section{Discussion}

The injection of progesterone before the introduction of males in the first experiment increased the frequency of normal CL in a dose-dependent manner but did not affect the incidence of ovulation or ovulation rate. Abnormal CL were only completely eliminated at the highest dose of $20 \mathrm{mg}$ which is identical with the dose suggested by Cognie et al. (1982). Whether lower doses were less effective because they failed to produce a sufficiently high concentration of progesterone or a critical concentration of progesterone over a sufficiently long period is unknown. The relationship of dose of progesterone to the proportion of ewes in Exp. 2 whose first oestrus was synchronized about Day 18 after the introduction of males showed differences when comparing the two highest with the lowest and zero doses of progesterone, despite highly significant effects on the life-span of 
$\mathrm{CL}$. The failure to demonstrate a consistent relationship was due in part to the high proportion of ewes ovulating spontaneously at the time of the experiment, and more importantly to the high proportion of the ewes that were induced to ovulate by the introduction of testosterone-treated wethers but that failed to re-ovulate and display oestrus 16-26 days later. The effects of progesterone on the distribution of oestrus were therefore dampened.

These experiments demonstrate some of the potential shortcomings of use of the 'ram effect' under commercial conditions. The flock had a relatively high proportion of ewes ovulating spontaneously and these were therefore unavailable to be stimulated by the introduction of rams, despite the fact that the anovulatory ewes in the flock were highly responsive to stimulation. Lindsay \& Signoret (1980) have previously shown that as the proportion of cyclic ewes increases sa does the responsiveness of the anovulatory ewes to the 'ram effect'. The ovulation rate of ewes that ovulated after the introduction of testosterone-treated wethers was higher than that of ewes ovulating spontaneously and agrees with the report of Cognie, Gayerie, Oldham \& Poindron (1980). Despite this, other observations (Pearce, Gray, Oldham \& Wilson, 1984) suggest that the introduction of rams does not always increase the ovulation rate of Merino ewes.

Almost all anovulatory ewes were induced to ovulate after the introduction of testosteronetreated wethers but only a few were subsequently detected in oestrus, most of the rest returned to an anovulatory state. Failure to re-ovulate and display oestrus has been reported previously by Oldham \& Cognie (1980), but in their studies most ewes displayed oestrus at least once before returning to an anovulatory state. Only ewes of the Ile-de-France breed induced to ovulate in the middle of their anoestrous season stopped ovulating within one oestrous cycle. The mechanisms underlying the phenomenon are unknown. The efficacy of the oestrous response was not affected by temporary withdrawal and reintroduction of testosterone-treated wethers, possibly because the ewes remained refractory to stimulation after such a short period of reisolation (Oldham, 1980).

Contrary to the findings of Murtagh et al. (1984), maiden ewes were as responsive to the 'ram effect' as the adult ewes in terms of induced ovulation but, as reported by Murtagh et al. (1984), significantly fewer ewes were subsequently detected in oestrus. Together these studies explain some of the reasons for the poor reproductive performance of young ewes in spring.

We thank the Australian Meat Research Committee for financial assistance; N. Garnet for provision of sheep; H. Wilson, D. Turner, I. Williams, J. Beesley and Liz Pearce for technical assistance; Mr G. De'Ath for statistical advice and D. R. Lindsay for help with preparation of the manuscript. D.T.P. was holder of the E.H.B. Lefroy Fellowship.

\section{References}

Alvey, N.G., Banfield, C.F., Baxter, R.I., Gower, J.C., Krzanowski, W.J., Lane, P.W., Leech, P.K., Nelder, J.A., Payne, R.W., Phelps, K.M., Rogers, C.E., Ross, G.J.S., Simpson, H.R., Todd, A.D., Wedderburn, R.W.M. \& Wilkinson, G.N. (1977) GENSTAT (A General Statistical Program). The Statistics Department, Rothamsted Experimental Station.

Cognie, Y., Gayerie, F., Oldham, C.M. \& Poindron, P. (1980) Increased ovulation rate at the ram-induced ovulation and its commercial application. Proc. Aust. Soc. Anim. Prod. 13, 80-82.

Cognie, Y., Gray, S.J., Lindsay, D.R., Oldham, C.M., Pearce, D.T. \& Signoret, J.P. (1982) A new approach to controlled breeding in sheep using the 'ram effect'. Proc. Aust. Soc. Anim. Prod. 14, 519-522.

Fulkerson, W.J., Adams, N.R. \& Gherardi, P.B. (1981)
The ability of wethers treated with oestrogens or testosterone to induce and detect oestrus in ewes. Appl. Anim. Ethol. 7, 57-66.

Lindsay, D.R. \& Signoret, J.P. (1980) Influence of behaviour on reproduction. Proc. 9th Int. Congr. Anim. Reprod. \& AI, Madrid 1, 83-92.

Murtagh, J.J., Gray, S.J., Lindsay, D.R. \& Oldham, C.M. (1984) The influence of the 'ram effect' in 10-11 month old Merino ewes on their subsequent performance when introduced to rams again at 15 months of age. Proc. Aust. Soc. Anim. Prod. 15, 490-493.

Nelder, J.R. \& Wedderburn, R.W.M. (1972) Generalized linear models. J. Royal Stat. Soc. 135, 370-384.

Oldham, C.M. (1980) Stimulation of ovulation in seasonally or lactationally anovular ewes by rams. Proc. Aust. Soc. Anim. Prod. 13, 73-74. 
Oldham, C.M. \& Cognie, Y. (1980) Do ewes continue to cycle after teasing? Proc. Aust. Soc. Anim. Prod. 13, 82-85.

Oldham, C.M. \& Lindsay, D.R. (1980) Laparoscopy in the ewe: a photographic record of the ovarian activity of ewes experiencing normal or abnormal oestrous cycles. Anim. Reprod. Sci. 3, 119-124.

Oldham, C.M. \& Martin, G.B. (1978) Stimulation of seasonally anovular Merino ewes by rams. Il. Premature regression of ram-induced corpora lutea. Anim. Reprod. Sci. 1, 291-295.

Oldham, C.M., Knight, T.W. \& Lindsay, D.R. (1976) A comparison of the effects on reproductive performance in sheep, of two methods of estimation of ovulation rate. Aust. J. exp. Agric. Anim. Husb. 16, 24- 27.
Oldham, C.M., Cognie, Y., Poindron, P. \& Gayerie, F. (1980) The influence of progesterone or FGA priming on the ovarian function of seasonally anovular ewes induced to ovulate by their re-introduction to rams, teasing. Proc. 9th Int. Congr. Anim. Reprod. \& AI, Madrid 3, 50.

Pearce, D.T., Gray, S.J., Oldham, C.M. \& Wilson, H.R. (1984) Alternative methods of synchronisation of ewes in spring using the 'ram effect'. 3. The use of intravaginal sponges and PMSG. Proc. Aust. Soc. Anim. Prod. 15, 164-168.

Schinckel, P.G. (1954) The effect of the presence of the ram on the ovarian activity of the ewe. Aust. J. agric. Res. 5, 465-469.

Received 25 October 1984 